\title{
EVALUASI SPT TAHUNAN ELEKTRONIK
}

\author{
Elsie Sylviana Kasim ${ }^{1}$ \\ Titin Fachriah Nur ${ }^{2}$ \\ 1,2Laboratorium Administrasi Perpajakan Program Vokasi Universitas Indonesia ,
elsiekasim@yahoo.com, titinfachrianur@yahoo.com
}

Diterima : 16 November 2015

Layak Terbit : 29 Desember 2015

\begin{abstract}
Abstrak
Evaluasi layanan SPT Tahunan Elektronik dilakukan untuk mengetahui kualitas pelayanan SPT Tahuanan Elektronik dengan menggunakan pendekatan konsep Service Quality (SERVQUAL) yaitu melalui dimensi tangibles, realibility, responsiveness, assurance dan empathy. Hasil penelitian dan analisis yang telah peneliti lakukan mengenai Evaluasi Layanan SPT Tahunan Elektronik, dapat ditarik kesimpulan Wajib Pajak "PUAS" dengan kualitas pelayanan SPT Tahunan Elektronik. Saran yang diberikan adalah situs djponline.pajak.go.id dibuat lebih memperhatikan kebutuhan Wajib Pajak. Dimana Situs djponline.pajak.go.id yang bagus tidak hanya memperhatikan fungsi tapi juga dapat meningkatkan kepercayaan terhadap layanan djponline.pajak.go.id.
\end{abstract}

Kata Kunci: Evaluasi layanan, SPT Tahunan Elektronik, Service Quality

\begin{abstract}
Evaluation of services of Electronic Annual Tax Return is conducted to determine the quality of services of Electronic Annual Tax Return. This is done by using the five Service Quality (SERVQUAL) dimensions which are tangibles, realibility, responsiveness, assurance and empathy. The result of the research and analysis of Evaluation of services of Electronic Annual Tax Return concluded that Taxpayers are satisfied with the quality of Electronic Annual Tax Return. Advices given to the djponline.pajak.go.id websites is it should be more attentive to the needs of the Taxpayers. Djponline.pajak.go.id websites should not only pay attention to the functions but also increased trust amoung Taxpayers toward djponline.pajak.go.id websites.
\end{abstract}

Keywords: Evaluation of services, Electronic Annual Tax Return, Service Quality

\section{PENDAHULUAN}

Direktorat Jenderal Pajak selain memiliki tugas mengumpulkan penerimaan negara, juga mempunyai tugas memberikan pelayanan kepada Wajib Pajak (Indonesian Tax Review, 2015, 26). Salah satu cara meningkatkan pelayanan pajak kepada Wajib Pajak yaitu dengan menggunakan layanan internet atau $e$ governance. E-Government atau biasa dikenal $e$ gov, pemerintah digital, online pemerintah atau pemerintah transformasi adalah suatu upaya untuk mengembangkan penyelenggaraan kepemerintahan yang berbasis elektronik. Suatu penataan sistem manajemen dan proses kerja di lingkungan pemerintah dengan mengoptimalkan pemanfaatan teknologi informasi dan komunikasi. E-Government dapat diaplikasikan pada legislatif, yudikatif, atau administrasi publik, untuk meningkatkan efisiensi internal, menyampaikan pelayanan publik, atau proses kepemerintahan yang demokratis. 
Direktorat Jenderal Pajak selaku administrator penerimaan negara dari sektor pajak telah menyelenggarakan e-gov. Hal ini sudah menjadi keharusan mengingat Direktorat Jenderal Pajak harus melayani lebih dari 26 juta Wajib Pajak dari seluruh Indonesia (Indonesian Tax Review, 2015, 36). Direktorat Jenderal Pajak telah menghadirkan layanan transactional web presence seperti pendaftaran online $(e-$ registration), pembayaran (e-billing) dan pelaporan (e-filing). E-Registration atau Sistem Pendaftaran Wajib Pajak secara Online adalah sistem aplikasi bagian dari Sistem Informasi Perpajakan di lingkungan Direktorat Jenderal Pajak dengan berbasis perangkat keras dan perangkat lunak yang dihubungkan oleh perangkat komunikasi data yang digunakan untuk mengelola proses pendaftaran Wajib Pajak. Sistem ini terbagi dua bagian, yaitu System yang dipergunakan oleh Wajib Pajak yang berfungsi sebagai sarana pendaftaran Wajib Pajak secara online dan system yang dipergunakan oleh Petugas Pajak yang berfungsi untuk memproses pendaftaran Wajib Pajak.

E-Billing adalah fasilitas elektronik yang telah disediakan Direktorat Jenderal Pajak berupa sistem pembayaran elektronik (billing system) yang memudahkan Wajib Pajak untuk membayarkan pajaknya dengan lebih mudah, lebih cepat, dan lebih akurat.

Sedangkan E-Filing adalah suatu cara penyampaian SPT atau pemberitahuan perpanjangan SPT Tahunan yang dilakukan secara on-line yang realtime melalui website Direktorat Jenderal Pajak atau Penyedia Jasa
Aplikasi atau Application Service Provider (ASP). Dalam penyampaian Surat Pemberitahuan Online atau e-filing, Wajib Pajak dapat menyampaikannya melalui 2 (dua) cara. Yang pertama melalui sarana Penyedia Jasa Aplikasi (ASP), berdasarkan Peraturan Direktur Jenderal Pajak Nomor PER47/PJ/2008 tentang Tata Cara Penyampaian Surat Pemberitahuan dan Penyampaian Pemberitahuan Perpanjangan Surat Pemberitahuan Tahunan Secara Elektronik (e-Filing) melalui Perusahaan Penyedia Jasa Aplikasi (ASP) sebagaimana telah diubah dengan PER-36/PJ/2013. Jenis surat pemberitahuan yang dapat disampaikan adalah seluruh jenis SPT baik masa maupun tahunan dan juga pemberitahuan perpanjangan SPT tahunan. Yang kedua melalui situs Pajak, berdasarkan Peraturan Direktur Jenderal Pajak Nomor PER1/PJ/2014 tentang Tata Cara Penyampaian Surat Pemberitahuan Tahunan Pajak Orang Pribadi yang Menggunakan Formulir 1770S atau 1770 SS secara e-Filing Melalui Situs Pajak. Jenis surat pemberitahuan yang dapat disampaikan adalah SPT Tahunan PPh Wajib Pajak Orang Pribadi formulir 1770 S dan 1770 SS.

SPT Tahunan PPh WP Orang Pribadi Formulir 1770 S digunakan bagi WP Orang Pribadi yang sumber penghasilannya diperoleh dari satu atau lebih pemberi kerja dan memiliki penghasilan lainnya yang bukan dari kegiatan usaha dan/atau pekerjaan bebas. Contohnya karyawan, Pegawai Negeri Sipil (PNS), Tentara Nasional Indonesia (TNI), Kepolisian Republik Indonesia (POLRI), serta 
pejabat Negara lainnya, yang memiliki penghasilan lainnya antara lain sewa rumah, honor pembicara/pengajar/pelatih dan sebagainya. Sedangkan SPT Tahunan PPh WP Orang Pribadi Formulir 1770SS adalah formulir yang digunakan oleh Wajib Pajak Orang Pribadi yang mempunyai penghasilan selain dari usaha dan/atau pekerjaan bebas dengan jumlah penghasilan bruto tidak lebih dari Rp60.000.000,00 setahun (pekerjaan dari satu atau lebih pemberi kerja).

Untuk dapat melakukan Penyampaian Surat Pemberitahuan Tahunan Pajak Orang Pribadi yang Menggunakan Formulir $1770 \mathrm{~S}$ atau 1770SS secara e-Filing Melalui Situs Pajak, melalui tiga tahapan utama. Dua tahapan yang pertama hanya dilakukan sekali saja. Sedangkan tahapan ketiga dilakukan setiap menyampaikan SPT. Ketiga tahapan tersebut meliputi:

1. Mengajukan permohonan $e-F I N$ ke Kantor Pelayanan Pajak terdekat yang merupakan nomor identitas WP bagi pengguna $e$ filing. Karena hanya sekali digunakan, Anda hanya perlu sekali saja mengajukan permohonan mendapatkan $e-F I N$ tersebut.

2. Mendaftarkan diri sebagai WP e-Filing di situs DJP paling lama 30 hari kalender sejak diterbitkannya $e-F I N$.

3. Menyampaikan SPT Tahunan PPh WP Orang Pribadi secara e-filing melalui situs DJP

melalui empat langkah prosedural saja, yaitu: (1) mengisi e-SPT pada aplikasi e-filing di situs DJP; (2) meminta kode verifikasi untuk pengiriman e-SPT, yang akan dikirimkan melalui email atau SMS; (3) mengirim SPT secara online dengan mengisikan kode verifikasi; dan (4) notifikasi status e-SPT dan Bukti Penerimaan Elektronik akan diberikan kepada WP melalui email.

Sekilas e-filling nampak begitu mudah, bahkan dalam situs DJP menyampaikan tujuh keuntungan bagi Wajib Pajak apabila menggunakan fasilitas e-Filing sebagai berikut:

1. Penyampaian SPT dapat dilakukan secara cepat, aman, dan kapan saja (24x7);

2. Murah, tidak dikenakan biaya pada saat pelaporan SPT;

3. Penghitungan dilakukan secara tepat karena menggunakan sistem komputer;

4. Kemudahan dalam mengisi SPT karena pengisian SPT dalam bentuk wizard;

5. Data yang disampaikan WP selalu lengkap karena ada validasi pengisian SPT;

6. Ramah lingkungan dengan mengurangi penggunaan kertas; dan

7. Dokumen pelengkap (fotokopi Formulir $1721 \mathrm{~A} 1 / \mathrm{A} 2$ atau bukti potong PPh, SSP Lembar ke-3 PPh Pasal 29, Surat Kuasa Khusus, perhitungan $\mathrm{PPh}$ terutang bagi WP Kawin Pisah Harta dan/atau mempunyai NPWP sendiri, fotokopi Bukti Pembayaran Zakat) tidak perlu dikirim lagi kecuali diminta oleh KPP melalui Account Representative (AR). 
Tabel 1.1 Jumlah WP Penggunaan e-Filing

Tahun 2008-2012

\begin{tabular}{|c|c|c|c|c|c|}
\hline $\begin{array}{c}\text { Tahun } \\
\text { Diterima } \\
\text { nya SPT }\end{array}$ & 2008 & 2009 & 2010 & 2011 & 2012 \\
\hline $\begin{array}{c}\text { Jmlh } \\
\text { WP OP }\end{array}$ & $\begin{array}{c}8.807 . \\
666\end{array}$ & $\begin{array}{c}13.861 . \\
253\end{array}$ & $\begin{array}{c}16.880 \\
649\end{array}$ & $\begin{array}{c}19.881 . \\
684\end{array}$ & $\begin{array}{c}22.131 . \\
323\end{array}$ \\
\hline $\begin{array}{c}\text { Jmlh } \\
\text { Penggun } \\
\text { a } e- \\
\text { filing }\end{array}$ & 1.619 & 2.427 & 4.941 & 9.850 & 21.799 \\
\hline
\end{tabular}

Sumber : Laporan Tahunan Ditjen Pajak Tahun 2012, www.pajak.go.id

Melalui Tabel 1.1 terlihat bahwa meskipun tren pengguna e-filing meningkat tiap tahun, namun jumlah pengguna e-filing masih rendah. Apabila dibandingkan dengan jumlah Wajib Pajak Orang Pribadi yang terdaftar, jumlah pengguna e-filing masih kurang dari 1\%. Peningkatan pengguna e-filing pada tahun 2013 dan 2014 juga tidak signifikan, yaitu sebesar 24.509 pada tahun 2013 dan 33.923 pada tahun 2014. Oleh karena itu, penelitian ini dimaksudkan untuk mencari alternatif/upaya peningkatan mutu pelayanan SPT Tahunan Elektronik. Sehingga peningkatan mutu pelayanan SPT Tahunan Elektronik bisa meningkatkan jumlah pengguna e-filling yang masih rendah, khususnya Wajib Pajak orang pribadi yang Penyampaian Surat Pemberitahuan Tahunan Pajak Orang Pribadi yang Menggunakan Formulir $1770 \mathrm{~S}$ atau $1770 \mathrm{SS}$ secara $e$-Filing.

\section{METODE}

\section{Pengumpulan Data}

1. Profil Responden

Responden terdiri dari 33 orang namun kuesioner yang dapat digunakan sebanyak 30 orang. Jumlah sampel yang kecil untuk survey terhadap kepuasan pelanggan adalah cukup umum. Reseponden merupakan staf pendidikan dan staf kependidikan Universitas Indonesia yang mengisi formulir SPT tahunan 2014 melalui sarana E filling. Formulir SPT yang diisi adalah atas penghasilan yang berasal dari satu atau lebih pemberi kerja (Form $1770 \mathrm{~S}$ dan $1770 \mathrm{SS}$ ).

2.Jangka Waktu dan Metode Pengumpulan Data

Kuesioner Persepsi disebarkan melalui data elektronik dan mendatangi langsung calon responden pada Fakultas Ilmu Administrasi UI, Program Vokasi UI dan Rektorat UI. Jangka waktu penyebaran kuesioner antara tanggal 15 Agustus 2015 sampai dengan tanggal 15 September 2015.

\section{Pengolahan Data}

1. Uji Validitas

Uji Validitas yang digunakan adalah uji validitas konstruk, dilakukan untuk mengukur adanya hubungan linier antara kriteria pengujian yang ada dalam kuesioener dengan menghitung koefiesien korelasi antara skor tiap kriteria pengujian untuk setiap responden dengan skor total jawaban dari masingmasing responden.

Metode yang digunakan untuk uji validitas adalah menggunakan Product Momen Pearson dengan menggunakan perangkat lunak Microsoft Excel. Jika $r$ hitung lebih besar dari $r$ tabel maka kriteria pengujian dinyatakan valid dan sebaliknya. Hasil hitung dari $r$ tabel, dengan jumlah responden 30 
orang maka $\mathrm{df}=30-2=28$ dan $\mathrm{r}$ tabel 0.063 .

Dari sebanyak 21 kritera pengujian yang mencakup 5 dimensi, seluruhnya dinyatakan valid.

Tabel 4.1 Uji Validitas Persepsi

\begin{tabular}{|l|c|c|c|}
\hline $\begin{array}{l}\text { Kode } \\
\text { Atribut }\end{array}$ & $\begin{array}{l}\text { Correlation } \\
\text { Pearson }\end{array}$ & R Tabel & Keterangan \\
\hline \multicolumn{4}{|c|}{ Dimensi Tangible (x1) } \\
\hline X1.1 & 0,913 & 0.063 & Valid \\
\hline X1.2 & 4,256 & 0.063 & Valid \\
\hline X1.3 & 2,860 & 0.063 & Valid \\
\hline X1.4 & 2,959 & 0.063 & Valid \\
\hline X1.5 & 2,517 & 0.063 & Valid \\
\hline \multicolumn{4}{|c|}{ Dimensi Reliability (x2) } \\
\hline X2.1 & 3,970 & 0.063 & Valid \\
\hline X2.2 & 4,409 & 0.063 & Valid \\
\hline X2.3 & 1,540 & 0.063 & Valid \\
\hline X2.4 & 1,763 & 0.063 & Valid \\
\hline X2.5 & 4,452 & 0.063 & Valid \\
\hline \multicolumn{4}{|c|}{ Dimensi Responsivenss (x3) } \\
\hline X3.1 & 2,748 & 0.063 & Valid \\
\hline X3.2 & 3,649 & 0.063 & Valid \\
\hline X3.3 & 3,918 & 0.063 & Valid \\
\hline X3.4 & 4,530 & 0.063 & Valid \\
\hline \multicolumn{5}{|c|}{ Dimensi Assurance (x4) } \\
\hline X4.1 & 4,111 & 0.063 & Valid \\
\hline X4.2 & 6,371 & 0.063 & Valid \\
\hline X4.3 & 5,358 & 0.063 & Valid \\
\hline X4.5 & 3,151 & 0.063 & Valid \\
\hline \multicolumn{4}{|c|}{ Dimensi Empathy (x5) } \\
\hline X5.1 & 4,516 & 0.063 & Valid \\
\hline X5.2 & 4,529 & 0.063 & Valid \\
\hline X5.3 & 3,265 & 0.063 & Valid \\
\hline
\end{tabular}

\section{Uji Reliabilitas}

Uji reliabilitas bertujuan untuk menunjukkan sejauh mana suatu hasil pengukuran relative konsisten dalam mengukur konsep yang akan diukur. Pengukuran reliabilitas terhadap variable dilakukan dengan menggunakan metode Cronbach's alpha. Perhitungan dengan menggunakan perangkat lunak Microsoft Excell.

Dari hasil perhitungan kuesioner data persepsi diperoleh nilai koefisien Cronbach's alpha sebesar 0,931. Data dikatakan baik (reliable) jika nilai alpha antara 0,8 dan 1.
Berdasarkan hal tersebut maka seluruh kuesioner dinyatakan reliabel.

3. Pengolahan Data Servqual

Menurut Parasuraman, pengukuran SERVQUAL dengan data yang berdistribusi tidak normal dihitung dengan cut off point, yaitu membandingkan antara data persepsi dengan median untuk tiap kategori pengukuran. Jika median yang dihitung dari masing kelompok lebih kecil dari rata-rata tiap atribut pengujian maka responden dinyatakan puas dan sebaliknya.

Hasil pengolahan data statistik untuk perhitungan median menggunakan prianti lunak SPSS untuk masing-masing dimensi adalah sebagai berikut :

Tabel 4.2 Mean, Median dan Standar Deviasi

Sumber : Pengolahan Data

\begin{tabular}{|c|c|c|c|c|c|c|}
\hline Dimensi & Mean & Median & $\begin{array}{c}\text { Standar } \\
\text { Deviasi }\end{array}$ & Range & Minimum & Maximum \\
\hline Tangible & 3,91 & 4,00 & 0,478 & 2 & 3 & 5 \\
\hline Reliability & 3,87 & 4,00 & 0,408 & 2 & 3 & 5 \\
\hline Responsiveness & 3,40 & 3,25 & 0,582 & 3 & 2 & 5 \\
\hline Assurance & 3,62 & 3,63 & 0,649 & 3 & 3 & 5 \\
\hline Empathy & 3,78 & 3,83 & 0,645 & 4 & 2 & 5 \\
\hline
\end{tabular}

\section{HASIL DAN PEMBAHASAN}

Evaluasi Layanan SPT Tahunan Elektronik Penyampaian SPT Tahunan Elektronik Melalui Website DJP

Peraturan Direktur Jenderal Pajak nomor PER-04/PJ/2015 menyebutkan bahwa Wajib Pajak dapat melaksanakan hak dan memenuhi kewajiban perpajakannya melalui DJP Online. DJP Online adalah suatu layanan yang ditujukan untuk Wajib Pajak melalui website 
DJP atau mobile devices. Beberapa hal yang harus diperhatikan dalam pelaporan SPT Tahunan elektronik melalui website DJP adalah sebagai berikut:

1. DJP Online dapat diakses melalui website www.pajak.go.id atau djponline.pajak.go.id

2. Untuk dapat melaksanakan hak dan memenuhi kewajiban perpajakannya melalui DJP Online, Wajib Pajak harus memiliki e-Fin (electronic filling identification number).

E-Fin adalah nomor identitas yang diterbitkan oleh DJP kepada Wajib Pajak yang melakukan transaksi elektronik dengan DJP. E-Fin diterbitkan oleh Kantor Pelayanan Pajak (KPP) berdasarkan permohonan Wajib Pajak yang ketentuannya adalah sebagai berikut:

1. Permohonan untuk memperoleh e-Fin disampaikan oleh Wajib Pajak dengan menggunakan formulir sebagaimana diaturdalam lamprian PER-04/PJ/2015.

2. Permohonan e-Fin yang disampaikan oleh Wajib Pajak dapat disampaikan ke KPP terdekat dengan syarat:

a. Menyerahkan fotokopi identitas diri dan fotokopi kartu NPWP atau fotokopi SKT; dan

b. Menunjukkan asli kartu identitas Wajib Pajak

3. Permohonan e-Fin yang disampaikan oleh Wajib Pajak badan harus disampaikan ke KPP terdaftar dengan syarat:

a. Menyerahkan fotokopi kartu NPWP atau fotokopi SKT;

b. Menyerahkan fotokopi identitas diri salah satu wakil Wajib Pajak dan fotokopi kartu
NPWP atau SKT wakil Wajib Pajak sesuai akta pendirian dan/atau akta perubahan terakhir;

c. Menyerahkan fotokopi akta pendirian dan/atau akta perubahan terakhir; dan

d. Menunjukkan asli kartu identitas diri salah satu wakil Wajib Pajak kepada petugas pajak.

4. E-Fin akan diterbitkan oleh KPP dalam jangka waktu 1 hari kerja setelah permohonan diterima lengkap dan benar.

5. E-Fin yang telah diterbitkan disampaikan langsung kepada Wajib Pajak, tidak dikirm melalui pos atau dengan cara lain.

6. E-Fin bersifat rahasia dan harus dijaga kerahasiaannya oleh Wajib Pajak.

7. Dalam hal e-Fin hilang, Wajib Pajak dapat mengajukan permohonan pencetakan ulang e-Fin.

8. Wajib Pajak yang telah memiliki e-Fin harus mendaftarkan diri dengan melakukan aktivasi melalui website www.pajak.go.id atau djponline.pajak.go.id paling lambat 30 hari sejak e-Fin diterbitkan. Apabila Wajib Pajak tidak melakukan pendaftaran diri dalam jangka waktu tersebut, maka e-Fin tersebut hangus/kadaluwarsa dan tidak dapat dipergunakan kembali.

9. Setelah melakukan registrasi, Wajib Pajak harus melakukan aktivasi akun dengan meng-klik link aktivasi yang dikirm melalui email yang sudah didaftarkan sebelumnya pada saat registrasi. 
10. Wajib Pajak yang telah mendaftarkan diri memperoleh username dan password. Username yang dipergunakan berupa NPWP 15 digit.

11. Username dan password tersebut dipergunakan untuk login ke djponline.pajak.

12. Melalui website tersebut Wajib Pajak dapat menyampaikan SPT Tahunan elektronik terbatas pada formulir $1770 \mathrm{~S}$ dan 1770 SS.Setelah login ke website tersebut, Wajib Pajak bisa mengisi SPT dengan menggunakan formulir yang sesuai dan mengikuti langkah-langkah yang diinstruksikan.

13. Dalam hal SPT Wajib Pajak menunjukkan status kurang bayar, Wajib Pajak harus mencantumkan NTPN atas pembayaran pajak yang kurang bayar tersebut sebagai bukti pembayaran.

14. Wajib Pajak harus memindai keterangan/dokumen lain yang harus dilampirkan dalam SPT Tahunan ke dalam format PDF dan mengunggahnya.

15. Setelah proses pengisian dan unggah dokumen selesai, Wajib Pajak meminta kode verifikasi. Kode verifikasi dikirimkan ke email Wajib Pajak dan harus memasukkan kode tersebut untuk mengirimkan SPT-nya. SPT dianggap lengkap apabila seluruh elemen data digitalnya telah diisi dan lampiran SPTnya telah diunggah.

16. Apabila SPT dianggap lengkap, kepada Wajib Pajak diberikan bukti penerimaan elektronik melalui email.

Tingkat Kepuasan Wajib Pajak terhadap Layanan SPT Tahunan Elektronik

Hasil pengolahan data terhadap kelima dimensi, yaitu tangible (berwujud), reliability (kehandalan), responsiveness (ketanggapan), assurance (jaminan) dan empathy (kesungguhan) menunjukkan secara keseluruhan responden merasa puas terhadap pelayanan pengisian dan pengiriman SPT melalui e-Filling. Pembahasan masing-masing dimensi adalah sebagai berikut :

\section{Dimensi Tangible (berwujud)}

Pada dimensi Tangible, responden diberikan 5 (lima) atribut penilaian yang ditentukan dari penampilan situs dan kelengkapan fungsi dalam menyelesaikan penyampaian formulir SPT Tahunan Elektronik. Dengan jumlah responden 30 orang, nilai perhitungan median Dimensi Tangible sebesar 4. Dari seluruh responden, sebanyak 19 orang atau sebanyak 63,3\% menjawab "PUAS", sedangkan 11 orang atau 36,7\% menjawab “TIDAK PUAS”

Tabel 5.1 Hasil Analisa SERVQUAL Dimensi

\begin{tabular}{|l|l|l|}
\multicolumn{3}{c}{ Tangible (Berwujud) } \\
\hline Kriteria Jawaban & Jumlah Responden & Persentase (\%) \\
\hline PUAS & 19 & 63,3 \\
\hline TIDAK PUAS & 11 & 36,7 \\
\hline Total & 30 & 100,0 \\
\hline \multicolumn{3}{|c|}{ Sumber : Pengolaan Data } \\
\hline
\end{tabular}




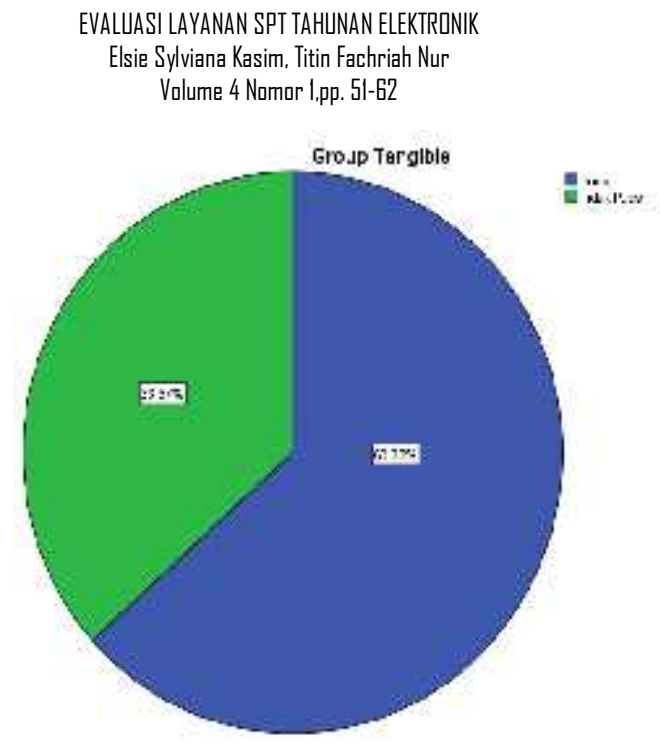

Gambar 5.1 Tingkat Kepuasan dan ketidakpuasan (\%) Dimensi Tangible (Berwujud)

2. Dimensi Reliability (kehandalan).

Dimensi Reliability (kehandalan) mengatur sejauh mana fungsi telah dijalankan secara konsisten. Dari 5 (lima) atribut penilaian yang ditentukan, nilai perhitungan median Dimensi Reliability (kehandalan) sebesar 4 . Sebanyak 16 orang atau sebanyak 53,3\% menjawab "PUAS", sedangkan 14 orang atau 46,7\% menjawab “TIDAK PUAS”.

Tabel 5.2 Hasil Analisa SERVQUAL Dimensi Reliability (Kehandalan)

\begin{tabular}{|c|c|c|}
\hline Kriteria Jawaban & $\begin{array}{c}\text { Jumlah } \\
\text { Responden }\end{array}$ & Persentase (\%) \\
\hline PUAS & 16 & 53,3 \\
\hline TIDAK PUAS & 14 & 46,7 \\
\hline Total & 30 & 100,0 \\
\hline \multicolumn{2}{|c|}{ Sumber : Pengolahan Data } \\
\hline
\end{tabular}

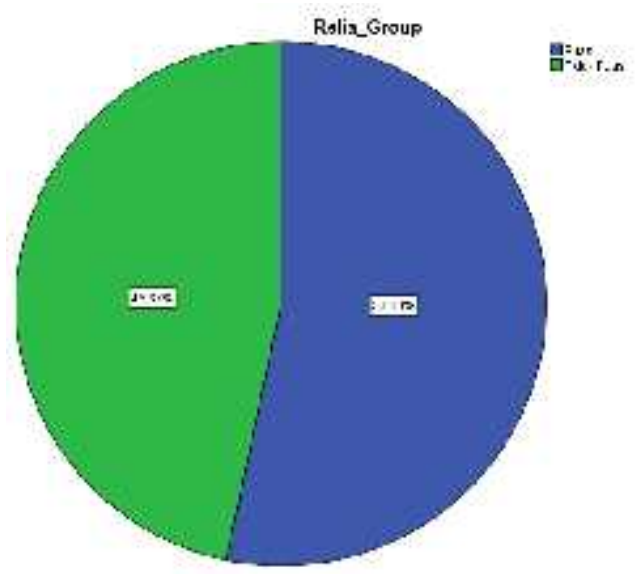

Gambar 5.2 Tingkat Kepuasan dan ketidakpuasan (\%) Dimensi Reliability (Kehandalan) Sumber : Pengolahan Data

3. Dimensi Responsiveness (ketanggapan)

Pada dimensi ini, responden diberikan sebanyak 4 (empat) atribut penilaian yang meliputi pelayanan yang memuaskan dan memastikan pelayanan ini siap setiap saat. Dengan jumlah responden 30 orang, nilai perhitungan median Dimensi Responsiveness (ketanggapan) sebesar 3,25. Dari seluruh responden, sebanyak 20 orang atau sebanyak 66,7\% menjawab "PUAS", sedangkan 10 orang atau 33,3\% menjawab “TIDAK PUAS”. 
Tabel 5.3 Hasil Analisa SERVQUAL Dimensi Responsiveness (Ketanggapan)

\begin{tabular}{|c|c|c|}
\hline Kriteria Jawaban & Jumlah Responden & Persentase (\%) \\
\hline PUAS & 20 & 66,7 \\
\hline TIDAK PUAS & 10 & 33,3 \\
\hline Total & 30 & 100,0 \\
\hline \multicolumn{3}{|c|}{ Sumber : Pengolahan Data } \\
\hline
\end{tabular}

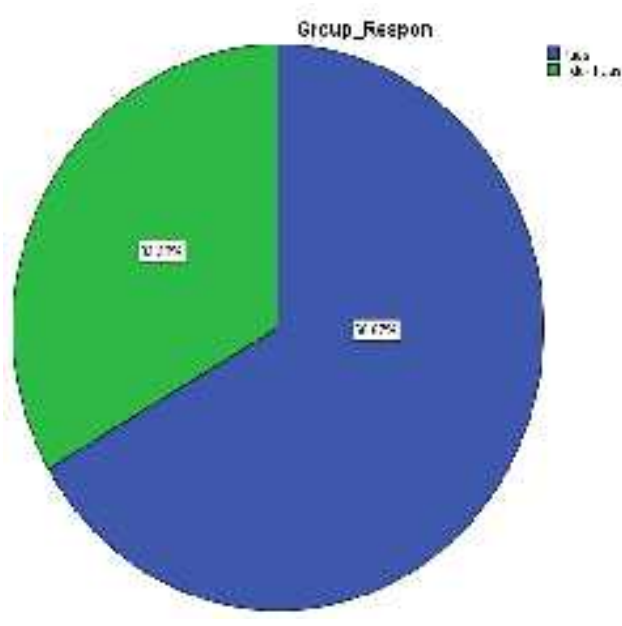

Gambar 5.3 Tingkat Kepuasan dan ketidakpuasan (\%) Dimensi Responsiveness (Ketanggapan) Sumber : Pengolahan Data

4.Dimensi Assurance (Jaminan)

Dimensi Assurance (Jaminan) meliputi pelayanan fungsi dimana responden berperan aktif dalam proses pembelajaran dengan suasana yang menyenangkan. Atribut penilaian antara lain apakah dampak dari penggunaan situs online terhadap tingkat penguasaan penyampaian SPT Tahunan elektronik, penguasaan terhadap isi dari formulir dan perbaikan terhadap kesalahan pengisian SPT yang dapat berdampak pada sanksi perpajakan. Nilai perhitungan median Dimensi Assurance (Jaminan) sebesar 3,63. Jumlah responden yang menjawab "PUAS" dan menjawab "TIDAK PUAS" sama banyaknya, yaitu masing-masing 15 orang atau $50 \%$.
Tabel 5.4 Hasil Analisa SERVQUAL Dimensi Assurance (Jaminan)

\begin{tabular}{|c|c|c|}
\hline Kriteria Jawaban & Jumlah Responden & Persentase (\%) \\
\hline PUAS & 15 & 50,0 \\
\hline TIDAK PUAS & 15 & 50,0 \\
\hline Total & 30 & 100,0 \\
\hline \multicolumn{2}{|c|}{ Sumber : Pengolahan Data } \\
\hline
\end{tabular}

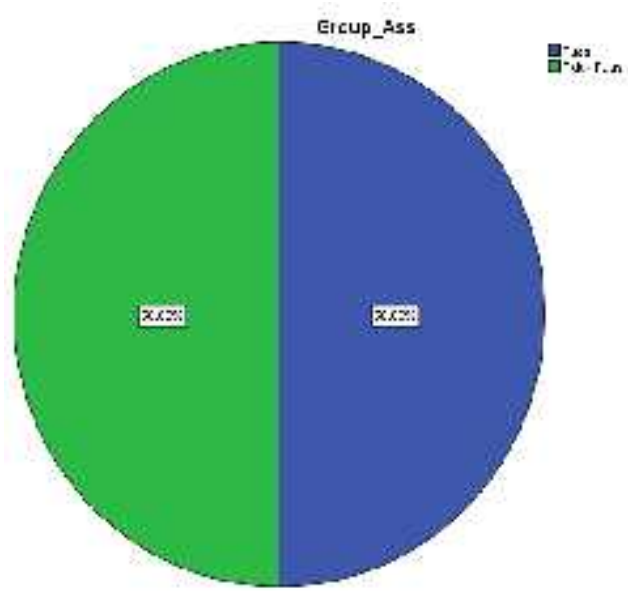

Gambar 5.4 Tingkat Kepuasan dan ketidakpuasan

(\%) Dimensi Assurance (Jaminan)

Sumber : Pengolahan Data

5. Dimensi Empathy (Kesungguhan)

Pada dimensi Empathy (Kesungguhan), responden diberikan 3 (tiga) atribut penilaian yang berhubungan dengan persepsi bahwa situs Direktorat Jenderal Pajak memberikan perhatian khusus kepada responden, seperti pada aspek perhitungan pajak, sesuai dengan kebutuhan responden dan aspek identitas responden. Nilai perhitungan median Empathy (Kesungguhan) sebesar 3,83. Sama dengan Dimensi Assurance, Jumlah responden yang menjawab "PUAS" dan menjawab "TIDAK PUAS” sama banyaknya, yaitu masing-masing 15 orang atau $50 \%$.

Tabel 5.5 Hasil Analisa SERVQUAL Dimensi Empathy (Kesungguhan)

\begin{tabular}{|c|c|c|}
\hline Kriteria Jawaban & Jumlah Responden & Persentase (\%) \\
\hline PUAS & 15 & 50,0 \\
\hline TIDAK PUAS & 15 & 50,0 \\
\hline Total & 30 & 100,0 \\
\hline \multicolumn{2}{|c|}{ Sumber : Pengolahan Data } \\
\hline
\end{tabular}




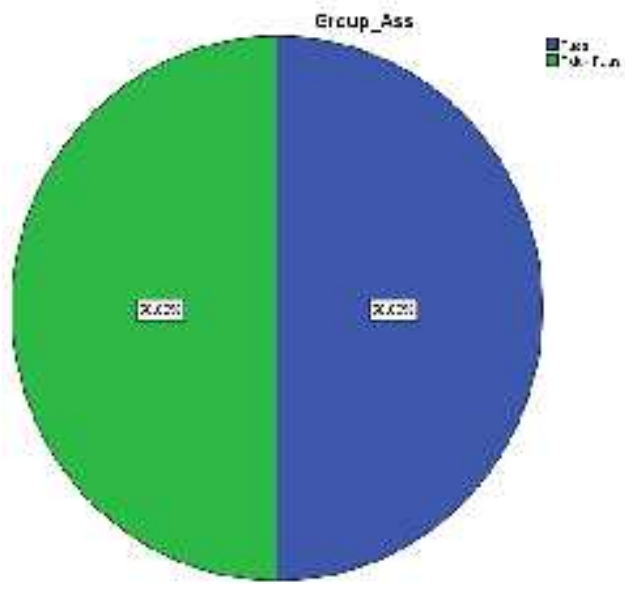

Gambar 5.5 Tingkat Kepuasan dan ketidakpuasan (\%) Dimensi Empathy (Kesungguhan) Sumber : Pengolahan Data

Hasil pengamatan secara keseluruhan terhadap 5 (lima) dimensi kualitas pelayanan adalah sebagai berikut :

Tabel 5.6 Hasil Keseluruhan SERVQUAL

\begin{tabular}{|c|c|c|c|}
\hline Dimensi & $\begin{array}{l}\text { Kriteria } \\
\text { Jawaban }\end{array}$ & $\begin{array}{c}\text { Jumlah } \\
\text { Responden }\end{array}$ & $\begin{array}{c}\text { Persentase } \\
(\%)\end{array}$ \\
\hline \multirow[t]{2}{*}{ Tangible } & Puas & 19 & 63,3 \\
\hline & Tidak Puas & 11 & 36,7 \\
\hline \multirow[t]{2}{*}{ Reliability } & Puas & 16 & 53,3 \\
\hline & Tidak Puas & 14 & 46,7 \\
\hline \multirow[t]{2}{*}{ Responsiveness } & Puas & 20 & 66,7 \\
\hline & Tidak Puas & 10 & 33,3 \\
\hline \multirow[t]{2}{*}{ Assurance } & Puas & 15 & 50,0 \\
\hline & Tidak Puas & 15 & 50,0 \\
\hline \multirow[t]{2}{*}{ Emphaty } & Puas & 15 & 50,0 \\
\hline & Tidak Puas & 15 & 50,0 \\
\hline \multirow{2}{*}{$\begin{array}{l}\text { Hasil rata-rata } \\
\text { Dimensi } \\
\text { SERVQUAL }\end{array}$} & Puas & 85 & 56,7 \\
\hline & Tidak Puas & 65 & 43,3 \\
\hline
\end{tabular}

Dapat diambil kesimpulan bahwa dimensi Responsiveness mempunyai kriteria jawaban “PUAS” tertinggi yaitu 66,7\%. Sedangkan Assurance dan Empathy mempunyai kriteria jawaban "PUAS" terendah yaitu 50,0\%. Hasil rata-rata dimensi SERVQUAL adalah “PUAS” 56,7\% dan “TIDAK PUAS” 43,3\%, hal ini menunjukkan bahwa Wajib Pajak "PUAS" atas pelayanan SPT Tahunan Elektronik.

\section{PENUTUP}

\section{Simpulan}

Dari hasil penelitian dan analisis yang telah peneliti lakukan mengenai Evaluasi Layanan SPT Tahunan Elektronik, dapat ditarik kesimpulan sebagai berikut:

Kualitas pelayanan SPT Tahunan Elektronik dapat disimpulkan "PUAS" sesuai dengan dimensi yang memiliki nilai terbesar hingga terkecil sebagai berikut:

1. Dimensi Responsiveness (Ketanggapan)

Situs djponline.pajak.go.id yang tanggap terhadap keperluan administrasi Wajib Pajak. Cepat memberikan tanggapan apabila ada kesalahan. Pertolongan yang tersedia setiap saat dan tanggap dalam mengatasi kesalahan menghasilkan kriteria jawaban "PUAS” 66,7\% dan “TIDAK PUAS” 33,3\%.

\section{Dimensi Tangible}

Penampilan situs djponline.pajak.go.id yang sesuai, menarik dan rapi. Situs telah menyajikan fungsi yang komprehensif dan memberikan pelayanan yang dibutuhkan Wajib Pajak, menghasilkan kriteria jawaban “PUAS” 63,3\% dan “TIDAK PUAS” 36,7\%.

\section{Dimensi Reliability}

Situs djponline.pajak.go.id yang dapat dipercaya. Situs telah menyelesaikan proses penyampaian SPT Tahunan Elektronik dalam tepat waktu sama seperti Wajib Pajak lainnya, menghasilkan kriteria jawaban "PUAS” 53,3\% dan “TIDAK PUAS” 33,3\%.

4. Dimensi Assurance (Jaminan)

Situs djponline.pajak.go.id membuat Wajib Pajak mahir dalam menyampaikan SPT 
Tahunan Elektronik. Wajib Pajak mudah memperbaiki kesalahan apabila salah menyampaikan SPT Tahunan Elektronik. Kesalahan dalam menyampaikan SPT Tahunan Elektronik tidak menimbulkan sanksi pajak, menghasilkan kriteria jawaban "PUAS" 50,0\% dan “TIDAK PUAS" 50,0\%

5. Dimensi Empathy (Kesungguhan)

Situs djponline.pajak.go.id membuat perhitungan pajak sesuai yang dinginkan Wajib Pajak. Situs mengetahui identitas Wajib Pajak, menghasilkan kriteria jawaban "PUAS” 50,0\% dan “TIDAK PUAS” 50,0\%.

\section{Saran}

Berdasarkan simpulan yang telah dibuat, saran yang dapat diberikan adalah sebagai berikut:

Situs djponline.pajak.go.id dibuat lebih memperhatikan kebutuhan Wajib Pajak. Perlu diterapkan kriteria kepercayaan pada situs djponline.pajak.go.id. Situs djponline.pajak.go.id yang bagus tidak hanya memperhatikan fungsi tapi juga dapat meningkatkan kepercayaan terhadap layanan djponline.pajak.go.id. Ketika Wajib Pajak menggunakan situs djponline.pajak.go.id seakan-akan Wajib Pajak sedang berinteraksi secara langsung dengan petugas pajak. profesional secara umum.

\section{DAFTAR PUSTAKA}

\section{Buku}

Douglas Holmes, 2001, eGov: eBusiness Strategies for Government, Nicholas Brealy Publishing, Londong

e-Government - 2nd Administrative Reform Commission, arc.gov.in/11threp/arc_11threport_ch2

History and Development of e-Government, 2001, shodhganga.inflibnet.ac.in/.../10_chapter-3

Laporan Tahunan Direktorat Jenderal Pajak Tahun 2012, www. Pajak.go.id

Sultoni, SE, 2015, PER03/PJ/2015: Selamat Datang Era SPT Elektronik, Era Papperless!, Indonesian Tax, Review

Tan and Cenfetelli, 2008, Building Citizen Trust towards E-Government Services: Do High Quality Websites Matter?, Conference Paper 
Zeithaml, Valerie, A, A. Parasuraman, and Leonard L. Berry, 1990, Delivering Quality Service (Balancing Customer Perceptions and Expectations), The Free Press, A Division of Macmillan, Inc, New York

\section{Peraturan Perundang-undangan}

Undang-undang nomor 28 Tahun 2007 tentang Ketetentuan Umum dan Perpajakan

Peraturan Menteri Keuangan nomor 243/PMK.03/2014 tentang Surat Pemberitahuan

Peraturan Direktur Jenderal Pajak nomor PER-03/PJ/2015 tentang penyampaian Surat Pemberitahuan

Elektronik 